УДК 616.314-74

DOI 10.11603/2311-9624.2018.1.8392

(С). Б. Костенко, I. Ю. Гангур, І. В. Сорокопуд, М. Ю. Гончарук-Хомин, Г. Н. Накашидзе

ДВНЗ «Ужгородський національний університет»

\title{
Аналіз методів оцінки та впливу полірованості композитних матеріалів на функціональний прогноз реставрацій
}

Резюме. Серед запропонованих критеріїв USPHS, одобрених FDI, рівень блиску та полірованості реставрацій відіграє одне з ключових значень для попередження не тільки таких ускладнень як дисколорації чи зміна їх текстури в майбутньому, а й для профілактики вторинного карієсу та дезінтеграції пломби, оскільки площі з підвищеною шорсткістю відіграють роль ретенційних пунктів для накопичення бактеріального нальоту та подальшого прогресування вищеописаних ускладнень.

Мета дослідження - провести аналіз методів оцінки якості полірування композитних реставрацій та визначити роль впливу фактора шорсткості їх поверхні на прогноз функціонування та зміну параметрів кольоростійкості, формування біоплівки та блиску.

Матеріали і методи. Пошук публікацій, суміжних із темою даного аналізу, проводили у пошуковій системі Google Scholar за ключовими словами «шорсткість», «полірованість», «композитні реставрації» та їх аналогів англійською мовою. Глибина пошуку з урахуванням віку ключових статей, що визначалися за рівнем цитованості у пізніших періодичних виданнях, не перевищувала 15 років. 3 метою систематизації отриманих даних використовували табличний редактор Microsoft Excel 2016 (Microsoft Office), у якому відбувалось групування попередньо відібраних статей за результатами контент-аналізу.

Результати досліджень та їх обговорення. В ході проведеного аналізу було встановлено, що основними лабораторними методами для оцінки параметру шорсткості поверхні реставрації як показника якості полірованості, виступають атомно-силова мікроскопія, скануюча електронна мікроскопія та профілометрія. Найчастіше з метою верифікації вищезгаданого параметру в проаналізованих дослідженнях використовували показник Ra - середнього арифметичного відхилення профілю, на основі аналізу якого вдалось встановити залежність можливостей досягнення відповідного рівня полірованості реставрацій від структури використовуваного композитного матеріалу, системи та етапності полірування, трибологічної природи взаємодії системи полірування та поверхні реставрації.

Висновки. Результати проведеного аналізу свідчать про те, що дані, отримані в ході попередніх клінічних та лабораторних досліджень щодо впливу та ефекту полірування на різні параметри реставрацій, є дискусійними та потребують більш конкретної систематизації з виокремленням досліджуваних аспектів змін блиску, шорсткості, кольоростійкості та функціонального прогнозу від методу полірування в окремі незалежні тематики для досліджень, з поетапним їх поєднанням після отримання однозначних чисельних даних, що піддаються відповідній об’єктивній інтерпретації.

Ключові слова: шорсткість; полірування; композитні реставрації.

\author{
(с). Б. Костенко, И. Ю. Гангур, И. В. Сорокопуд, М. Ю. Гончарук-Хомин, \\ Г. Н. Накашидзе \\ ГВУЗ «Ужгородский национальный университет»
}

\section{Анализ методов оценки и влияния полированости композитных материалов на функциональный прогноз реставраций}

Резюме. Среди предложенных критериев USPHS, одобренных FDI, уровень блеска и полированости реставраций играет одно из ключевых значений для предупреждения не только таких осложнений как дисколорация или изменение их текстуры в будущем, но и для профилактики вторичного кариеса и дезинтеграции пломбы, поскольку площади с повышенной шероховатостью играют роль ретенционных пунктов для накопления бактериального налета и дальнейшего прогрессирования вышеописанных осложнений.

Цель исследования - провести анализ методов оценки качества полировки композитных реставраций и определить роль влияния фактора шероховатости их поверхности на прогноз их функционирования и изменение параметров цветоустойчивости, формирование биопленки и блеска. 
Материалы и методы. Поиск публикаций смежных с темой данного анализа проводился в поисковой системе Google Scholar по ключевым словам «шероховатость», «полированость», «композитные реставрации» и их аналогов на английском языке. Глубина поиска с учетом возраста ключевых статей, которые определялись по уровню цитируемости в более поздних периодических изданиях, не превышала 15 лет. С целью систематизации полученных данных использовали табличный редактор Microsoft Excel 2016 (Microsoft Office), в котором проводили группировку предварительно отобранных статей по результатам контент-анализа.

Результаты исследований и их обсуждение. В ходе проведенного анализа было установлено, что основными лабораторными методами для оценки параметра шероховатости поверхности реставрации, как показателя качества полированости, выступают атомно-силовая микроскопия, сканирующая электронная микроскопия и профилометрия. Чаще всего с целью верификации вышеупомянутого параметра в проанализированных исследованиях использовали показатель Ra - среднего арифметического отклонения профиля, на основе анализа которого удалось установить зависимость возможностей достижения соответствующего уровня полированости реставраций от структуры используемого композитного материала, системы и этапности полировки, трибологической природы взаимодействия системы полировки и поверхности реставрации.

Выводы. Результаты проведенного анализа свидетельствуют о том, что данные, получены в ходе предыдущих клинических и лабораторных исследований влияния и эффекта полировки на различные параметры реставраций, являются дискуссионными и требуют более конкретной систематизации с выделением исследуемых аспектов изменения блеска, шероховатости, цветоустойчивости и функционального прогноза от метода полировки в отдельные независимые тематики для исследований, с поэтапным их сочетанием после получения однозначных многочисленных данных, подвергающихся соответствующей объективной интерпретации.

Ключевые слова: шероховатость; полированость; композитные реставрации.

\section{CS. B. Kostenko, I. Y. Hangur, I. V. Sorokopud, M. Y. Goncharuk- Khomyn, G. N. Nakashidze}

Uzhhorod National University

\section{Analysis of the methods of evaluation and influence of polishing of composite materials on the functional forecast of restorations}

Summary. Among the proposed USPHS criteria approved by FDI, the level of gloss and polishing of restorations plays a key role in preventing not only such complications as disocorporations or changes in their texture in the future, but also preventing secondary caries and sealing disintegration, since areas with high roughness play the role of retention points for the accumulation of bacterial plaque and the further progression of the above-described complications.

The aim of the study - to analyze the methods for assessing the quality of polishing composite restorations and to determine the role of influence roughness factor of their surface on the prediction of their functioning and change of color stability parameters, formation of biofilm and shine.

Materials and Methods. Search of publications related to the topic of this analysis was conducted by the Google Scholar search engine by the keywords "roughness», "polishing», "composite restorations» and their analogues in English. The depth of search, taking into account the age of key articles, determined by the level of their citation in later periodicals, did not exceed 15 years. In order to organize the received data, Microsoft Excel 2016 (Microsoft Office) table editor was used to group pre-selected articles based on the results of the provided content analysis.

Results and Discussion. In the course of the analysis, it was established that the basic laboratory methods for assessing the roughness of the restoration surface, as an indicator of the quality of polishing, are atomic force microscopy, scanning electron microscopy and profilometry. Most often, in order to verify the aforementioned parameter in the analyzed studies, the Ra value of mean arithmetic deviation of the profile was used, on the basis of which analysis it was possible to determine the dependence of the possibilities for achieving the corresponding level of restoration polishing on the structure of the composite material used, the system and phases of polishing, and the tribological nature of the interaction of the polishing system and the surface of the restoration.

Conclusions. The results of the analysis show that the data obtained in the course of previous clinical and laboratory studies dedicated to the effect of polishing on various restoration parameters are debatable and a more specific systematization is required, with the selection of the investigated aspects of brightness, roughness, color stability and functional prediction changes due to the polishing method in separate 
independent subjects for research, with further phased combination of them after obtaining unambiguous numerical data, subjected to appropriate objective interpretation.

Key words: roughness; polishing; composite restoration.

Вступ. Якість лікування дефектів твердих структур зубів визначають шляхом комплексної оцінки параметрів реставрації та прогнозом довгострокового її функціонування [1, 2]. За даними J. Peytron (2004) та M. Morgan (2004), фінішна обробка та полірування реставрації відіграють роль на етапах відтворення первинної, вторинної та навіть третинної анатомії зуба в ході відновлення його порушених функціонально-естетичних параметрів [3, 4]. Аналогічно значиму роль даним процедурам було надано і в структурі алгоритму формування прямих композитних реставрацій за технікою Style Italiano, згідно з якою вони мають особливе значення при моделюванні макро- та мікротекстури поверхонь відреставрованих зубів [5]. С. S. Jones та співавт. (2006) сформували наступний ряд обгрунтувань для проведення фінішної обробки та полірування поверхні реставрацій, які включали: 1) зниження вираження недосконалих елементів поверхні реставрації; 2) зменшення площі поверхні, таким чином мінімізуючи ризик можливого злому; 3) видалення надлишків матеріалу та формування країв; 4) зменшення шорсткості поверхні; 5) підвищення гладкості поверхні для мінімізації здатності акумулювати зубний наліт; 6) покращення функції жування (оскільки рідина та їжа легше рухаються по відполірованій поверхні зубів); 7) забезпечення достатнього доступу до всіх поверхонь зубів з метою оптимізації процедури гігієнічного догляду в майбутньому; 8) забезпечення гладкого інтерфейсу контакту реставрації, що дозволить мінімізувати вплив стирання поверхонь матеріалів різної щільності; 9) забезпечення естетичного профілю відмодельованих реставрацій [6]. У публікаціï R. Jefferies (2007), окрім понять фінішна обробка та полірування, виділяє також такий термін як маргінація [7]. За визначенням автора, фінішна обробка передбачає видалення крайових іррегулярностей, формування кінцевих анатомічних контурів та згладження шорсткості поверхні реставрації. Після виконання процедур фінішної обробки іде етап маргінації - специфічний процес, що передбачає видалення надлишку композитного матеріалу на межі його з'єднання із структурою зуба з формуванням гладкого, однорідного та адекватно адаптованого порожнинно-поверхневого краю. Полірування ж проводять після етапів фінішної обробки та маргінації для видалення візуальних подряпин із поверхні реставрації та надання їй необхідного рівня блиску.

Серед запропонованих критеріїв USPHS, одобрених FDI, рівень блиску та полірованості реставрацій відіграє одне з ключових значень для попередження не тільки таких ускладнень як дисколорації чи зміна ії текстури в майбутньому, а й для профілактики вторинного карієсу та дезінтеграції пломби, оскільки площі 3 підвищеною шорсткістю відіграють роль ретенційних пунктів для накопичення бактеріального нальоту та подальшого прогресування вищеописаних ускладнень [8]. Проте клінічні підходи до оцінки якості полірування реставрації, що існують сьогодні, характеризуються своєю суб'єктивністю і не забезпечують можливості отримання жодних чисельних даних для проведення відповідного об'єктивного аналізу ефективності фінішної обробки. Використання ж прикладного програмного забезпечення 3 перспективою графічного аналізу чи лабораторних методів дослідження забезпечує широкі можливості для комплексного аналітико-синтетичного опрацювання зон інтересу самої реставрації та її меж із резидуальними тканинами зубам. Таким чином, розробка та оптимізації підходів до оцінки якості проведеної фінішної обробки та полірування фотокомпозитних реставрацій із використанням прикладного програмного забезпечення та лабораторних методів дослідження залишається актуальним науково-практичним питанням сучасної стоматології.

Метою дослідження було провести аналіз методів оцінки якості полірування композитних реставрацій та визначити роль впливу фактора шорсткості їх поверхні на прогноз функціонування та зміну параметрів кольоростійкості, формування біоплівки та блиску. Виокремити найпоширеніші методи верифікації показників шорсткості поверхні та значущі критерії оцінки. Проаналізувати відповідність даних попередньо проведених до- 
сліджень з точки зору залежності якості полірування від структури композитів, специфіки систем, які використовують для обробки композитних матеріалів.

Матеріали і методи. Пошук публікацій, суміжних із темою даного аналізу, проводили у пошуковій системі Google Scholar за ключовими словами «шорсткість», «полірованість», «композитні реставрації» та їх аналогів англійською мовою. Глибина пошуку з урахуванням віку ключових статей, що визначали за рівнем цитованості у пізніших періодичних виданнях, не перевищувала 15 років. 3 метою систематизації отриманих даних використовували табличний редактор Microsoft Excel 2016 (Microsoft Office), у якому групування статей, попередньо відібраних шляхом контентаналізу, їх резюме проводили за такими параметрами, як «визначальна мета дослідження», «використовувані методи», "отримані результати», «рівні достовірності отриманих результатів», «клінічне значення отриманих результатів», після чого використовуючи принципи простеження тенденцій статистичних змін, внутрішньотекстових порівнянь, зіставлення контент-аналітичних та інших джерел проводили інтерпретацію отриманих даних.

Результати досліджень та їх обговорення. Ефективність процедур полірування та фінішної обробки, незалежно від протоколу проведення даних маніпуляцій, залежить від таких факторів, як структурні та механічні особливості матеріалу, який обробляють, різниці в твердості між субстратом полірування та інструментів для фінішної обробки пломби, твердість, розмір та форма частинок, які використовують в абразивному агенті, а також від фізичних параметрів матеріалу, що з'єднує усі частини абразиву в однорідну субстанцію, швидкості та тиску абразиву на субстрат обробки та використання різного роду речовин, які змащують під час проведення даних маніпуляцій (води, водорозчинних полімерів, гліцеролу та ін.). Трибологічний характер змін під час фінішної обробки композитних реставрацій та їх полірування може відбуватися за двома сценаріями: шляхом взаємодії трьох або ж лише двох складових. Взаємодія трьох складових елементів відбувається при наявності між поверхнею, яку треба відполірувати, та власне полірувальним інструментом проміжного матеріалу, за типом паст на основі кремнезему, алюмінію оксиду, чи з аналогічними включеннями. Взаємодія двох складових відбувається при безпосередній дії на поверхню полірування різного роду цільових борів, абразивів, стрічок без додаткового використання інших матеріалів на межі інтерфейсу їх взаємодії [7].

Відповідно до Міждержаваного стандарту, виділено 6 параметрів для оцінки шорсткості, які поділяють на три групи: висотні (Ra - ceреднє арифметичне відхилення профілю; Rz висота нерівностей профілю по 10 точках; Rmax - найбільша висота профілю), крокові (S - середній крок місцевих виступів профілю; Sm - середній крок нерівностей профілю по середній лініі) та висотно-крокові (tр - відносна опорна довжина профілю). Відповідно параметр шорсткості можна оцінювати за одним із вищезгаданих параметрів, або ж шляхом аналізу декількох 3 них [9, 10]. В оригінальному дослідженні L. Marigo (2001) та співавт. оцінку якості полірування поверхні композитного матеріалу проводили з використанням 3D-профілометра, що дозволяв кількісно визначити параметри шорсткості поверхні [11]. При цьому дослідникам вдалось встановити об'єктивні значення таких параметрів: середній показник шорсткості, середні квадратичні показники, значення профілометра відносно центральної лінії порівняння та величину кривизни профілю шорсткості. Таким чином, вченим вдалось мінімізувати вплив різного роду похибок під час об'єктивної оцінки рівня шорсткості поверхні, а відтак забезпечити чисельний підхід до встановлення якості полірування композитних реставрацій різними системами. Аналогічний підхід пізніше розвинули у дослідженнях G. Ozgunaltay та співавт. (2003) [12], A. R. Yazici (2007) (з використання безконтактної інтерферометрії) [13], F. Pettini (2015) [14], S. Nair та співавт. (2016) [15]. L. Giacomelli та співавт. (2010) апробували методи визначення шорсткості поверхні за допомогою атомно-силової мікроскопії та програмного забезпечення WSxM. Проте в даному дослідженні не було запропоновано жодних критеріїв оцінки полірування реставрацій, а відмінності, визначені між різними підходами до фінішної обробки, виявились статистично незначними [16]. E. Can Say та колеги (2014), додавши до вищезгаданого методу ще й додатковий аналіз із використанням скануючої електронної мікроскопї̈, встановили, що полірування нанонаповнених композитів за двоетапним протоколом забезпечує кращі результати однорідності поверхні, ніж полірування наногідбридних та мікрогідрибних композитів аналогічним методом [17]. 
Ю. П. Земсков та колеги (2015) представили метод оцінки шорсткості поверхні зубів із використанням лазерного профілометру, при цьому для того, щоб лікар міг самостійно контролювати процес шліфування (полірування) поверхні, автори запропонували наступну блок-схему: спочатку проводять оцінку наявності глянцевого блиску на поверхні емалі, після цього вибирають параметр довжини хвилі по лазерному профілометру, визначають чи довжина хвилі лазера відповідає нормі (якщо ні, то проводять налаштування довжини хвилі лазера на робочий діапазон профілометра), на наступному етапі виконують вибір параметра шорсткості поверхні зуба, якщо така відповідає довірчому інтервалу прояву блиску, то роблять висновок, що вдалось досягнути рівномірного глянцевого блиску (якщо показник шорсткості не відповідає довірчому інтервалу прояву блиску - проводять перерахунок шорсткості в довірчому інтервалі). Розробка даного алгоритму базувалась на тому, що попередньо дослідникам вдалось виявити залежність між шорсткістю полірованої поверхні зуба і довжиною хвилі лазерного променя профілометра [18]. Якість же відполірованості поверхні стоматологічних реставрацій може визначатися за показником шорсткості поверхні: чим більша шорсткість поверхні, тим вища потреба в додатковому поліруванні та шліфуванні реставрації. Фізично шорсткість поверхні визначають як кількісну характеристику нерівностей, яку виражають у числових величинах, що визначають ступінь відхилення даних нерівностей на базовій довжині. Ступінь же даного відхилення визначають відносно теоретично гладких поверхонь відповідної геометричної форми.

У роботі О. М. Кавчука та співавт. (2012) було описано метод оцінки якості полірування реставрації, який базувався на комп’ютерному аналізі цифрових зображень оброблених поверхонь пломб [19]. Вихідною умовою використання даного методу є наявність попередньо створеної еталонної бази, за даними якої в майбутньому можливо проводити аналітичні порівняння. Згідно з алгоритмом, який запропонували автори, в адаптованому програмному забезпеченні вимірюють площу ділянок різного ступеня полірування та відстань між ними, після чого забезпечують перерахунок координат зображення в метричні одиниці. Якщо площа недостатньо відполірованої поверхні реставрації перевищує 10 \%, можна розцінювати якість полірування як незадовільне. Проте такий підхід дозволяє оцінити лише величину недостатньо заполірованої поверхні, й не забезпечує оцінку якості проведеного полірування на різних ділянках реставрації в умовах їх візуально достатньої фiнішної обробки. 3 іншого боку, використання показника однорідності полірування в якості критерію якості фінішної обробки реставрацій дозволяє верифікувати найпроблемніші ділянки зубів після відновлення їх естетичної і функціональної цілості з використанням фотокомпозитів. Запропонований алгоритм опрацювання графічних зображень дозволяе проводити калібровку таких порівняно з відтінком реставрації та зуба, а також автоматично візуалізувати ділянки недостатньої полірованості шляхом перерахунку координат зображення в метричні одиниці. Враховуючи, що об’єктивізація показника полірування досі залишається відкритим науково-практичним питанням, використання параметрів однорідності полірованих поверхонь дозволяє оцінити ефективність проведеної процедури фінішної обробки реставрації та може бути рекомендованою для використання в ході комплексної оцінки якості надання стоматологічної допомоги населенню.

У дисертаційній роботі О. М. Челях (2010) вперше запропонував класифікацію показників шорсткості поверхні й, виходячи з них, класифікацію полірування фотополімерних композитів. У авторському підході розподіл числових параметрів шорсткості в класифікації зумовлено груповою належністю реставраційного матеріалу, що підлягав фінішній обробці, а саме, його фізико-механічними та оптичними властивостями, та визначався відповідно до технологічних процесів обробки поверхонь з використанням різних полірувальних систем, що дозволяють отримати відповідні кількісні значення шорсткості [20]. Виходячи із отриманих показників, автори також запропонували конкретні визначення мікрошорсткості та макрошорсткості, які можуть слугувати додатковими критеріями для оцінки якості кінцевої обробки композитної реставрації.

За даними А. Yazici та колег (2010), було встановлено, що фінішна обробка та полірування реставрацій дозволяють досягти вищих показників твердості композитного матеріалу залежно від алгоритму його полімеризації (з чи без використання майларової стрічки або гліцерину) [22]. При цьому зростання мікро- 
твердості поверхні реставрації до 30 \% спостерігалося через декілька днів після завершення процедури полірування від 105-113 HV до майже 145 HV. D. Venturini та колеги (2006) звернули увагу на проблему вибору адекватного терміну для проведення полірування, встановивши, що негайне полірування не проявляє негативного ефекту на параметри твердості поверхні реставрації мікро- та макрогібридних композитів, а деякі зразки, що були відполіровані негайно, продемонстрували навіть кращі результати функціонування, ніж ті, що були відполіровані відстрочено [23].

Значно багато досліджень встановили, що ефект розвитку біоплівки та можливого забарвлення реставрації залежить не так від можливостей полірування, як від структури самого композитного матеріалу (мікро-, макро-, нано- чи гібридного за наповненням), яка і визначала перспективу мінімізації ефекту шорсткості поверхні. G. Cazzaniga та колеги (2017) також встановили, що однозначних залежностей між параметрами шорсткості та гладкості поверхонь реставрацій та прогресом формування біоплівки S. mutans на досліджуваних ділянках реставрації встановити не вдалось [24]. Проте вони встановили вплив хімічного складу композиту на динаміку формування бактеріального нальоту. S. Glauser та колеги (2017) шляхом використання методу флуоресцентної мікроскопії та спектроскопії довели вищу динаміку формування біоплівки на більш шорстких поверхнях композитів, хоча така залежність була констатована не при усіх протоколах реалізації процесу полірування, і в окремих групах порівняння остання була статистично незначимою, хоча і наявною [25].

Вивчаючи параметр Ra (середнє арифметичне відхилення профілю) в результаті полірування композитів для формування реставрацій у ділянці дистальних зубів, Y. Hanadi та колеги (2010) встановили, що структура матеріалу є одним з визначальних факторів для досягнення відповідного рівня відполірованості: так менш шорстких поверхонь у ході полірування вдалось досягнути при обробці композитів, які катіонно полімеризуються з розкриттям циклу, та композитів, модифікованих керамікою, порівняно з матеріалами на основі диметикрилатів [26]. Використовуючи методи 60-кутової глосиметрії та інтерферометричної профілометрії білим світлом, N. S. Ereifej та колеги (2013) довели, що тип композиту та специфіка процедури полірування визначають кінцевий рівень шорсткості поверхні реставрації, а також і рівень блиску [27]. Аналогічні результати було отримано U. Erdermir та колегами (2013), які для аналогічних досліджень використовували метод профілометрії та скануючої електронної мікроскопії [28]. При цьому між рівнями показника шорсткості Ra мікрогібридного композиту та нанонаповненого не було відмічено жодної статистично значимої різниці, а склоіономерний цемент, навпаки, продемонстрував найвищий рівень шорсткості поверхні, що було обгрунтовано специфікою структури даного виду матеріалів. Такі ж результати отримали E. Can Say та колеги (2014): супрананонаповнені композити демонстрували найнижчі показники Ra після полірування двоетапною полірувальною системою, разом з тим, як мікрогібриди - найвищі [17]. Паралельно з цим дослідники довели кращий ефект полірування системи Enhance/PoGo, порівняно з системою Venus Supra у відповідній групі вибірки композитів, хоча в аналогічній вибірці композитів тієї ж групи наповненості, але уже іншого бренду - аналогічні різниці не були значимими, в кінцевому результаті супрананонаповнені матеріали демонстрували кращі параметри полірування порівняно з наногібридами. Однак у дослідженні J. Da Costa та колег (2007), навпаки, жодних статистично значимих кореляцій між видом композиту та використаною полірувальною системою з точки зору остаточного рівня шорсткості поверхні не відмічалось ( $p=0,059)$ [29]. 3 іншого боку дослідникам вдалось встановити взаємозв’язок між досягненим рівнем блиску та використаною полірувальною системою ( $<<0,001)$, таким чином, відмітивши що найвищий рівень блиску був при поліруванні матеріалу Supreme (нанонаповненого) системою Pogo (одноетапною), а найнижчий - при поліруванні Z100 системою Jiffy. Таким чином, також вдалось довести, що використання одноетапної системи полірування може забезпечити отримання результатів ефективності виконання маніпуляції, аналогічних багатоетапним системам. Berger та колеги (2011), провівши дослідження, апробуючи різні системи полірування на композитах із різним розміром частинок наповнювача, також дійшли висновку, що саме вибір системи полірування впливає на остаточні показники шорсткості поверхні реставрації [30]. Використовуючи в ході двоетапного підходу Enhance + PoGo (Dentsply Caulk), дослідники не виявили жодної статистичної різниці 
між параметрами шорсткості композитів різного ступеня наповненості. P. Senawongse та колеги (2007) відмітили, що при поліруванні нанокомпозитів рівень полірованості їх поверхонь практично не залежить від полірувальних систем, які використовують і при обробці матеріалів такого наповнення можна досягти найбільшого згладження поверхні реставрації [31]. Дослідникам також вдалось встановити важливий факт взаємозалежностей між результатами електронної мікроскопії, яка визначає нерівності поверхонь, та результатами, отриманими при тестуванні рівня шорсткості поверхонь. S. A. Antonson та співавт. (2011) дійшли висновку, що до моменту полірування вихідні рівні шорсткості нанонаповненого та мікрогібридного матеріалу в лабораторних умовах приготування зразків статистично відрізняються, однак дана різниця нівелюється при правильному підході до вибору оптимальних полірувальних/фінішних систем [32]. Після аналізу результатів системного огляду даних лабораторних досліджень, M. R. Kaizer та колеги (2014) констатували той факт, що поки що немає жодних лабораторно-обгрунтованих доказів того, що нанонаповнені композити або ж їх субмікронно наповнені аналоги є кращими матеріалами вибору, порівняно з традиційними мікрогібридами, з огляду на можливість досягнення відповідних параметрів гладкості та блиску Ïx поверхонь, або ж з огляду на ретенцію специфічних поверхневих характеристик матеріалу при дії на нього відповідних факторів впливу [33].

Висновки. У проведеному досліджені було встановлено, що основними лабораторними

\section{Список літератури}

1. Порівняльна оцінка поверхневої шорсткості та мікроструктури різних мікрогібридних фотополімерних композитних матеріалів залежно від способу їх полімеризації / В. Ф. Макєєв, 3. Ю. Готра, Н. І. Микиєвич, І. Г. Чучмай // Новини стоматології. - 2012. - № 2. - С. 84-89.

2. Удод О. А. Новітні підходи до оцінки якості фінішної обробки реставрацій фронтальних зубів / О. А. Удод, О. М. Челях // Вісник проблем біології і медицини. - 2014. - № 2. - С. 193-195.

3. Peyton J. H. Finishing and polishing techniques: direct composite resin restorations / J. H. Peyton // Practical Procedures and Aesthetic Dentistry. - 2004. - No. 16. P. 293-298.

4. Morgan M. Finishing and polishing of direct posterior resin restorations / M. Morgan // Practical Procedures and Aesthetic Dentistry. - 2004. - No. 16. - P. 211-234.

5. Gönülol N. The effects of finishing and polishing методами для оцінки параметру шорсткості поверхні реставрації, як показника якості полірованості, виступають атомно-силова мікроскопія, скануюча електронна мікроскопія та профілометрія. Найчастіше з метою верифікації вищезгаданого параметру в проаналізованих дослідженнях використовували показник $\mathrm{Ra}$ - середнього арифметичного відхилення профілю, на основі аналізу якого вдалось встановити залежність можливостей досягнення відповідного рівня полірованості реставрацій від структури композитного матеріалу, який використовують системи та етапності полірування, трибологічної природи взаємодії системи полірування та поверхні реставрації. Результати проведеного аналізу свідчать про те, що дані, отримані в ході попередніх клінічних та лабораторних досліджень щодо впливу та ефекту полірування на різні параметри реставрацій, є дискусійними та потребуються більш конкретної систематизації 3 виокремленням досліджуваних аспектів змін блиску, шорсткості, кольоростійкості та функціонального прогнозу від методу полірування в окремі незалежні тематики для досліджень, 3 поетапним ïx поєднанням після отримання однозначних чисельних даних, що піддаються відповідній об’єктивній інтерпретації.

Перспективи подальших досліджень полягають у подальшій розробці методів комп’ютерного графічного аналізу зображень фотографій поверхонь реставрацій, та встановлення факту чи рівня їх зв’язку із даними суміжно проведених профіломтеричних досліджень 3 метою оптимізації процесу оцінки якості полірування в ході функціонально-естетичної реабілітації стоматологічних пацієнтів.

techniques on surface roughness and color stability of nanocomposites / N. Gönülol, F. Yllmaz // Journal of Dentistry. - 2012. - No. 40. - P. 64-70.

6. Jones C. S. Interoperator variability during polishing / C. S. Jones, R. W. Billington, G. J. Pearson // Quintessence International. - 2006. - No. 37. - P. 187-190.

7. Jefferies S. R. Abrasive finishing and polishing in restorative dentistry: a state-of-the-art review / S. R. Jefferies // Dental Clinics of North America. - 2007. No. 51. - P. 379-397.

8. Mopper K. W. Finishing and polishing. Using the best tool to achieve natural-looking results / K. W. Mopper // Inside Dent. - 2013. - No. 9. - P. 90-92.

9. Сіренко Г. О. Моделі нанометричної та мікрометричної шорсткості поверхні твердих тіл : огляд / Г. О. Сіренко, Л. М. Солтис // Фізика і хімія твердого тіла. - 2010. - № 11. - С. 423-446.

10. Сіренко Г. О. Властивості полімерного композиту 
під час тертя та зношування по ізотропній та анізотропній шорсткій поверхні твердого тіла / Г. О. Сіренко, Л. М. Солтис // Математичні методи в хімії і біології. - 2014. - № 1. - С. 105-126.

11. 3-D surface profile analysis: different finishing methods for resin composites / L. Marigo, M. Rizzi, G. La Torre, G. Rumi // Operative Dentistry. - 2001. No. 26. - P. 562-568.

12. Özgünaltay G. Effect of finishing and polishing procedures on the surface roughness of new toothcoloured restoratives / G. Özgünaltay, A. R. Yazici, J. Görücü // Journal of Oral Rehabilitation. - 2003. - No. 30. - P. 218-224.

13. Yazici A. R. Three-dimensional surface profile analysis of different types of flowable restorative resins following different finishing protocols / A. R. Yazici, A. Müftü, G. Kugel // J. Contemp. Dent. Pract. - 2007. No. 8. - P. 1-11.

14. Roughness analysis on composite materials (microfilled, nanofilled and silorane) after different finishing and polishing procedures / F. Pettini, M. Corsalini, M. G. Savino [et al.] // The Open Dentistry Journal. - 2015. - No. 9. - P. 357-367.

15. Three-dimensional evaluation of surface roughness of resin composites after finishing and polishing / V. S. Nair, S. Sainudeen, P. Padmanabhan [et al.] // Journal of Conservative Dentistry: JCD. - 2016. - No. 19. - P. 91-95.

16. Surface roughness of commercial composites after different polishing protocols: an analysis with atomic force microscopy / L. Giacomelli, G. Derchi, A. Frustaci [et al.] // The Open Dentistry Journal. - 2010. - No. 4. - P. 191-194.

17. Surface roughness and morphology of resin composites polished with two-step polishing systems / E. C. Say, H. Yurdagüven, B. C. Yaman, F. Özer // Dental Materials Journal. - 2014. - No. 33. - P. 332-342.

18. К вопросу о применении методики контроля шероховатости шлифованной зубной поверхности / Ю. П. Земсков, А. А. Афанасьев, А. Н. Пегина, Р. В. Лесников // Научные ведомости Белгородского государственного университета. Серия : Медицина. Фармация. - 2015. - № 30. - С. 207.

19. Кавчук О. М. Оцінка ефективності клінічного застосування гібридного реставраційного матеріалу spektrum (ТРН 3) / О. М. Кавчук, Т. С. Гараніна, I. П. Краснюк // Буковинський медичний вісник. 2012. - № 16. - С. 64.

20. Удод О. А. Клінічна оцінка якості поверхні фронтальних реставрацій зубів / О. А. Удод, О. М. Челях // Питання експериментальної та клінічної медицини. - 2013. - №17. - С. 333-338.

21. Удод О. А. Новітні підходи до оцінки якості фінішної обробки реставрацій фронтальних зубів / О. А. Удод, О. М. Челях // Вісник проблем біології і медицини. - 2014. - № 2. - С. 193-195.

\section{References}

1. Makieiev, V.F., Hotra, Z.Yu., Mykyievych, N.I., \& Chuchmai, I.H. (2012). Porivnialna otsinka poverkhnevoi shorstkosti ta mikrostruktury riznykh mikrohibrydnykh fotopolimernykh kompozytnykh materialiv zalezhno vid sposobu yikh polimeryzatsii [Comparative estimation of surface roughness and microstructure of various microhybrid photopolymer
22. Effects of delayed finishing/polishing on surface roughness, hardness and gloss of tooth-coloured restorative materials / A. R. Yazici, D. Tuncer, S. Antonson [et al.] // European Journal of Dentistry. - 2010. - No. 4. P. 50-56.

23. Effect of polishing techniques and time on surface roughness, hardness and microleakage of resin composite restorations / D. Venturini, M. S. Cenci, F. F. Demarco [et al.] // Oper. Dent. - 2006. - No. 31. P. 11-17.

24. In vitro biofilm formation on resin-based composites after different finishing and polishing procedures / G. Cazzaniga, M. Ottobelli, A. Ionescu [et al.] // Journal of Dentistry. - 2017. - No. 67. - P. 43-52.

25. Bacterial colonization of resin composite cements: influence of material composition and surface roughness / S. Glauser, M. Astasov-Frauenhoffer, J. A. Müller [et al.] // European Journal of Oral Sciences. - 2017. - No. 125 (4). - P. 294-302.

26. Marghalani H. Y. Effect of finishing/polishing systems on the surface roughness of novel posterior composites / H. Y. Marghalani // Journal of Esthetic and Restorative Dentistry. - 2010. - No. 22. - P. 127-138.

27. Ereifej N. S. The effect of polishing technique on 3-D surface roughness and gloss of dental restorative resin composites / N. S. Ereifej, Y. G. Oweis, G. Eliades // 2012. - No. 38. - P. E9-E20.

28. Erdemir U. The effect of one-step and multi-step polishing systems on the surface roughness and microhardness of novel resin composites / U. Erdemir, H. S. Sancakli, E. Yildiz. // European Journal of Dentistry. - 2012. - No. 6. - P. 198-205.

29. The effect of different polishing systems on surface roughness and gloss of various resin composites / J. D. Costa, J. Ferracane, R. D. Paravina [et al.] // Journal of Esthetic and Restorative Dentistry. - 2007. - No. 19. P. 214-224.

30. Surface roughness and staining susceptibility of composite resins after finishing and polishing / S. B.Berger, A. R. Palialol, V. Cavalli, M. Giannini // Journal of Esthetic and Restorative Dentistry. - 2011. No. 23. - P. 34-43.

31. Senawongse P. Surface roughness of nanofill and nanohybrid resin composites after polishing and brushing / P. Senawongse, P. Pongprueksa // Journal of Esthetic and Restorative Dentistry. - 2007. - No. 19. P. 265-273.

32. Comparison of different finishing/polishing systems on surface roughness and gloss of resin composites / S. A. Antonson, A. R. Yazici, E. Kilinc [et al.] // Journal of Dentistry. - 2011. - No. 39. - P. e9-e17.

33. Do nanofill or submicron composites show improved smoothness and gloss? A systematic review of in vitro studies / M. R. Kaizer, A. de Oliveira-Ogliari, M. S. Cenci [et al.] // Dental Materials. - 2014. - No. 30. - P. e41-e78.

composite materials depending on the method of their polymerization]. Novyny stomatolohii - News of Dentistry, 2, 84-89 [in Ukrainian].

2. Udod, O.A., \& Cheliakh, O.M. (2014). Novitni pidkhody do otsinky yakosti finishnoi obrobky restavratsii frontalnykh zubiv [New approaches to the assessment of the quality of the finishing treatment of restorations 
of frontal teeth]. Visnyk problem biolohii i medytsyny Journal of Problems of Biology and Medicine, 2 (2), 193195 [in Ukrainian].

3. Peyton, J.H. (2004). Finishing and polishing techniques: direct composite resin restorations. Practical Procedures and Aesthetic Dentistry, 16 (4), 293-298.

4. Morgan, M. (2004). Finishing and polishing of direct posterior resin restorations. Practical Procedures and Aesthetic Dentistry, 16 (3), 211-234.

5. Gönülol, N., \& Yllmaz, F. (2012). The effects of finishing and polishing techniques on surface roughness and color stability of nanocomposites. Journal of Dentistry, 40, e64-e70.

6. Jones, C.S., Billington, R.W., \& Pearson, G.J. (2006). Interoperator variability during polishing. Quintessence International, 37 (3).

7. Jefferies, S.R. (2007). Abrasive finishing and polishing in restorative dentistry: a state-of-the-art review. Dental Clinics of North America, 51 (2), 379-397.

8. Mopper, K. W. (2013). Finishing and polishing. Using the best tool to achieve natural-looking results. Inside Dent., 9, 90-92.

9. Sirenko, H.O., \& Soltys, L.M. (2010). Modeli nanometrychnoi ta mikrometrychnoi shorstkosti poverkhni tverdykh til (Ohliad) [Models of nanometric and micrometric roughness of the surface of solids (Overview)]. Fizyka i khimiia tverdoho tila - Physics and Chemistry of a Solid, 11 (2), 423-446 [in Ukrainian].

10. Sirenko, H.O., \& Soltys, L.M. (2014). Vlastyvosti polimernoho kompozytu pid chas tertia ta znoshuvannia po izotropnii ta anizotropnii shorstkii poverkhni tverdoho tila [Properties of a polymer composite during friction and wear on an isotropic and anisotropic rough surface of a solid]. Matematychni metody $v$ khimii $i$ biolohii - Mathematical Methods in Chemistry and Biology, 2 (1), 105-126.

11. Marigo, L., Rizzi, M., La Torre, G., \& Rumi, G. (2001). 3-D surface profile analysis: different finishing methods for resin composites. Operative Dentistry, 26 (6), 562-568. 12. Özgünaltay, G., Yazici, A. R., \& Görücü, J. (2003). Effect of finishing and polishing procedures on the surface roughness of new tooth-coloured restoratives. Journal of Oral Rehabilitation, 30 (2), 218-224.

13. Yazici, A. R., Müftü, A., \& Kugel, G. (2007). Threedimensional surface profile analysis of different types of flowable restorative resins following different finishing protocols. J. Contemp. Dent. Pract., 8 (5), 1-11.

14. Pettini, F., Corsalini, M., Savino, M. G., Stefanachi, G., Di Venere, D., Pappalettere, C., \& Boccaccio, A. (2015). Roughness analysis on composite materials (microfilled, nanofilled and silorane) after different finishing and polishing procedures. The Open Dentistry Journal, 9, 357. 15. Nair, V.S., Sainudeen, S., Padmanabhan, P., Vijayashankar, L.V., Sujathan, U., \& Pillai, R. (2016). Three-dimensional evaluation of surface roughness of resin composites after finishing and polishing. Journal of Conservative Dentistry: JCD, 19 (1), 91.

16. Giacomelli, L., Derchi, G., Frustaci, A., Bruno, O., Covani, U., Barone, A., \& Chiappelli, F. (2010). Surface roughness of commercial composites after different polishing protocols: an analysis with atomic force microscopy. The Open Dentistry Journal, 4, 191.

17. Say, E.C., Yurdaguven, H., Yaman, B.C., \& Özer, F. (2014). Surface roughness and morphology of resin composites polished with two-step polishing systems. Dental Materials Journal, 33 (3), 332-342.

18. Zemskov, Yu.P., Afanasyev, A.A., Pegina, A.N., \& Lesnikov, R.V. (2015). K voprosu o primenenii metodiky kontrolya sherokhovatosti shlifovannoy zubnoy poverkhnosti [To the question of applying a roughness control technique to a grinding tooth surface]. Nauchnye vedomosti Belgorodskogo gosudarstvennogo universiteta. Seriya: Meditsyna. Farmatsyya - Scientific Reports of Belgorod State University. Series: Medicine. Pharmacy, 30 (10), 207 [in Russian].

19. Kavchuk, O.M., Garanina, T.S., \& Krasnyuk, I.P. (2012). Otsinka efektyvnosti klinichnoho zastosuvannia hibrydnoho restavratsiinoho materialu spectrum (TPH 3) [Evaluating the effectiveness of the clinical use of spectrum hybrid restoration material (TPH 3)]. Bukovynskyi medychnyi visnyk - Bukovyna Medical Journal, 16 (4), 81 [in Ukrainian].

20. Udod, O.A., \& Cheliakh, O.M. (2013). Klinichna otsinka yakosti poverkhni frontalnykh restavratsii zubiv [Clinical assessment of the surface quality of frontal restoration of teeth]. Pytannia eksperymentalnoi ta klinichnoi medytsyny - Issues of Experimental and Clinical Medicine, 17 (1), 333-338.

21. Udod, O.A., \& Cheliakh, O.M. (2014). Novitni pidkhody do otsinky yakosti finishnoi obrobky restavratsii frontalnykh zubiv [New approaches to the assessment of the quality of the finishing treatment of restorations of frontal teeth]. Visnyk problem biolohii i medytsyny Journal of Biology and Medicine Problems, 2 (2), 193-195. 22. Yazici, A. R., Tuncer, D., Antonson, S., Onen, A., \& Kilinc, E. (2010). Effects of delayed finishing/polishing on surface roughness, hardness and gloss of toothcoloured restorative materials. European Journal of Dentistry, 4 (1), 50-56.

23.Venturini,D.,Cenci, M.S., Demarco,F.F., Camacho, G.B., \& Powers, J.M. (2006). Effect of polishing techniques and time on surface roughness, hardness and microleakage of resin composite restorations. Operative Dentistry, 31 (1), 11-17.

24. Cazzaniga, G., Ottobelli, M., Ionescu, A. C., Paolone, G., Gherlone, E., Ferracane, J.L., \& Brambilla, E. (2017). In vitro biofilm formation on resin-based composites after different finishing and polishing procedures. Journal of Dentistry, 67, 43-52.

25. Glauser, S., Astasov-Frauenhoffer, M., Müller, J.A., Fischer, J., Waltimo, T., \& Rohr, N. (2017). Bacterial colonization of resin composite cements: influence of material composition and surface roughness. European Journal of Oral Sciences, 125 (4), 294-302.

26. Marghalani, H.Y. (2010). Effect of finishing/ polishing systems on the surface roughness of novel posterior composites. Journal of Esthetic and Restorative Dentistry, 22 (2), 127-138.

27. Ereifej, N.S., Oweis, Y.G., \& Eliades, G. (2012). The effect of polishing technique on 3-D surface roughness and gloss of dental restorative resin composites. Operative Dentistry, 38 (1), E9-E20.

28. Erdemir, U., Sancakli, H.S., \& Yildiz, E. (2012). The effect of one-step and multi-step polishing systems on the surface roughness and microhardness of novel resin composites. European Journal of Dentistry, 6 (2), 198-205. 29. Costa, J.D., Ferracane, J., Paravina, R.D., Mazur, R.F., \& Roeder, L. (2007). The effect of different polishing 


\section{Терапевтична стоматологія}

systems on surface roughness and gloss of various resin composites. Journal of Esthetic and Restorative Dentistry, 19 (4), 214-224.

30. Berger, S.B., Palialol, A.R.M., Cavalli, V., \& Giannini, M. (2011). Surface roughness and staining susceptibility of composite resins after finishing and polishing. Journal of Esthetic and Restorative Dentistry, 23 (1), 34-43.

31. Senawongse, P., \& Pongprueksa, P. (2007). Surface roughness of nanofill and nanohybrid resin composites after polishing and brushing. Journal of Esthetic and Restorative Dentistry, 19 (5), 265-273.
32. Antonson, S.A., Yazici, A.R., Kilinc, E., Antonson, D.E., \& Hardigan, P.C. (2011). Comparison of different finishing/ polishing systems on surface roughness and gloss of resin composites. Journal of Dentistry, 39, e9-e17.

33. Kaizer, M.R., de Oliveira-Ogliari, A., Cenci, M.S., Opdam, N.J., \& Moraes, R.R. (2014). Do nanofill or submicron composites show improved smoothness and gloss? A systematic review of in vitro studies. Dental Materials, 30 (4), e41-e78. 